\title{
The Diversity And Classification Of Intraspecies Of Gembolo (Dioscorea Bulbifera L.) Based On Morphological Character
}

\author{
Andri Prasetia ${ }^{1}$, Purnomo $^{2}$, Budi Setiadi Daryono ${ }^{3}$ \\ ${ }^{1}$ Department of Agrotechnology, Faculty of Agriculture, Musamus University, Jl. Kamizaun, Mopah Lama, \\ Merauke, Papua 99616, Indonesia \\ ${ }^{2}$ Laboratory of Plant Systematics, Faculty of Biology, Gadjah Mada University, Jl. Teknika Selatan, Mlati, \\ Sleman, Special Region of Yogyakarta 55281, Indonesia \\ ${ }^{2}$ Laboratory of Genetics, Faculty of Biology, Gadjah Mada University, J1. Teknika Selatan, Mlati, Sleman, \\ Special Region of Yogyakarta 55281, Indonesia
}

\begin{abstract}
Gembolo (Dioscorea bulbifera L.) is a dioecious, annual, herbaceous, climbing plants and has heart-shaped leaves. Gembolo has aerial tubers (bulbil) and main tuber that has irregular shapes, as well as many rough roots at the base of the stem. The purpose of this research is to know the phenetic relationship of the germplasm of Gembolo in Special Region of Yogyakarta based on morphological character. The results of this study are expected to provide information on intraspecies diversity, phenetic relationship and Gembolo distribution. Gembolo plant samples were taken from D.I Yogyakarta. The sample was observed based on the difference of morphological character, so the number of accessions obtained from D.I Yogyakarta could be determined. Morphological characters would be described and characterized to determine the Operational Taxonomic Units (OTU's). Based on morphological character data, then the grouping analysis was done by grouping analysis method and the dendrogram was formed by the method of Unweighted Pair Group Methods using Arithmetic averages (UPGMA) using Multivariate Statistical Program (MVSP) software version 3.1pc. The results showed that gembolo had morphological variation in tuber shape, stem color, leaf shape, leaf base shape and leaf tip shape. Based on the morphological characters, 2 main groups with the value of similarity index of $62,8 \%$ was formed. Group I consisted of four accessions with a similarity value of $85 \%$. Group II consisted of eight accessions with a similarity value of $75 \%$. A high similarity based on the morphological character on gembolo accession caused the gembolo plants in Special Region of Yogyakarta did not vary.
\end{abstract}

Keywords: Gembolo, phenetic relationship, intraspecies classification

\section{Introduction}

There are approximately 600 species of genus Dioscorea in the world, spread across Africa and Asia. Dioscorea plants in Asia are from Southeast Asia, then spread to India, Peninsular Malaysia and Pacific. There are about 50-60 species that have been cultivated and used as food and medicinal plants [3].

Gembolo is naturally shade- and drought-tolerant, a climbing plant and producing tubers underground. Gembolo is one of the plants that become the source of carbohydrates and has a strategic potential as one of the food reserves in the future. Dioscorea has a superiority when compared with other tuber crops because it is easy to grow in critical areas without significant treatment [8].
In Yogyakarta (Indonesia), there are several Dioscorea plants that are still planted by the community, such as Gembolo (Dioscorea bulbifera L.). Gembolo is naturally shade- and drought-tolerant, a climbing plant and producing tubers underground. Gembolo is one of the plants that become the source of carbohydrates and has a strategic potential as one of the functional food reserves in the future. Dioscorea has a superiority when compared with other tuber crops because it is easy to grow in critical areas without significant treatment [8].

Characterization is one method that is used to know the diversity of a plant. Characterization can be done through multiple markers, including morphological markers. Morphological markers are important to be done because the presence of morphological characterization is the

\footnotetext{
*Corresponding author: andri_prasetia@ymail.com
} 
preliminary data to complement the information of plant diversity.

The morphological diversity of Gembolo tubers (Dioscorea bulbifera L.) that has not been identified in Yogyakarta is interesting to be done. The identification is done to determine the similarity of Gembolo based on the morphological diversity of tubers. The result of the characterization of diversity and similarity of Gembolo plant can be used to determine the potential of tubers variant of Gembolo as an effort to develop the cultivation technique. The characterization data can be used to support food crop breeding and germplasm conservation programs in Indonesia.

Gembolo plants from various regions in Yogyakarta have not been well characterized, so it needs to be characterized to know the potential of these plants that can be used to meet the basic needs. Characterization is done through morphological markers.

\section{Research Methods}

\subsection{Materials}

Gembolo (Dioscorea bulbifera L.) sample collection was taken from Special Region of Yogyakarta covering Bantul Regency, Gunungkidul Regency, Kulon Progo Regency, Sleman Regency. The sample was in the form of underground tubers and aerial tubers. The sample was then planted in the experimental garden at the Faculty of Biology of Gadjah Mada University.

Table 1. List of gembolo collections obtained from the field in Special Region of Yogyakarta

\begin{tabular}{cllll}
\hline No & Collection No & Local Name & & Origin \\
\hline $\mathbf{1}$ & KP-01 & Gembolo/ mbolo & Subdistrict of Temon, Kulon Progo Regency & Yellow Gembolo \\
$\mathbf{2}$ & BT-01 & Gembolo/ mbolo & Bantul Regency & Yellow Gembolo \\
$\mathbf{3}$ & BT-02 & Gembolo/ mbolo & Bantul Regency & Yellow Gembolo \\
$\mathbf{4}$ & BT-03 & Gembolo/ mbolo & Bantul Regency & Yellow Gembolo \\
$\mathbf{5}$ & SL-01 & Gembolo/ mbolo & Subdistrict of Prambanan, Sleman Regency & Yellow Gembolo \\
$\mathbf{6}$ & SL-02 & Gembolo/ mbolo & Subdistrict of Prambanan, Sleman Regency & Yellow Gembolo \\
$\mathbf{7}$ & SL-03 & Gembolo/ mbolo & Subdistrict of Prambanan, Sleman Regency & Yellow Gembolo \\
$\mathbf{8}$ & SL-04 & Gembolo/ mbolo & Subdistrict of Prambanan, Sleman Regency & Yellow Gembolo \\
$\mathbf{9}$ & SL-05 & Gembolo/ mbolo & Subdistrict of Prambanan, Sleman Regency & Yellow Gembolo \\
$\mathbf{1 0}$ & SL-06 & Gembolo/ mbolo & Subdistrict of Prambanan, Sleman Regency & Yellow Gembolo \\
$\mathbf{1 1}$ & SL-07 & Gembolo/ mbolo & Subdistrict of Prambanan, Sleman Regency & Yellow Gembolo \\
$\mathbf{1 2}$ & SL-08 & Gembolo/ mbolo & Subdistrict of Prambanan, Sleman Regency & Yellow Gembolo \\
\hline
\end{tabular}

(Source: researchers' personal document)

\subsection{Data retrieval}

The morphological data obtained were observed descriptively then characterized. The morphological data that have been characterized in the form of quantitative (binary) and qualitative (multistate) characters were converted into numerical data, by making tiered scores according to preliminary data, referring to the descriptor writing provisions created by the International Plant Genetic Resources Institute [2]. Qualitative characters need to be standardized using standardize program. The grouping of matrix data (cluster analysis) was done using Unweighted Pair Group Methods using Arithmetic averages (UPGMA) method (Singh, 1999) with the formulation of Gower General Similarity Coefficient on MVSP software version $3.1 \mathrm{pc}$ [7].

Table 2. Character that was observed for morphological data of IPGRI modification

\begin{tabular}{cll}
\hline No & \multicolumn{1}{c}{ Characters } & \multicolumn{1}{c}{ Scores } \\
\hline 1. & Color of a stem & $0=$ Green, $1=$ Purplish Green; $2=$ Purple; $3=$ Greenish Purple \\
\hline 2. & Wax layer on the stem & $0=$ None; $1=$ Available \\
\hline 3 & Stem base shape & $0=$ Octagon; $1=$ Spherical \\
\hline 4 & Leaf shape & $0=$ Sagittate; $1=$ Cordate \\
\hline 5 & Leaf tip shape & $0=$ caudate $1=$ acuminate \\
\hline 6 & Shape of leaf blade base & $0=$ Cordate; $1=$ Sagittate \\
\hline 7 & Young leaf color & $0=$ Purple; $1=$ Green \\
\hline 8 & Mature leaf color & $0=$ Light green; $1=$ Dark green \\
\hline 9 & Petiole length & $0=$ Short $(<5 \mathrm{~cm}) ; 1=$ Medium $(5-10 \mathrm{~cm}) ; 2=$ Long $(>10 \mathrm{~cm})$ \\
\hline 10 & Petilole color & $0=$ Green; $1=$ Purple \\
\hline 11 & Underground tuber & $0=$ None; $1=$ Available \\
\hline 12 & Number of underground tuber & $0=$ One; $1=$ More than one \\
\hline 13 & Underground tuber shape & $0=$ Spherical (reguler $) ; 1=$ Irregular \\
\hline 14 & Underground tuber size & $3=$ Small; $5=$ Medium; $7=$ Large \\
\hline 15 & Underground tuber bark color & $0=$ Light brown; $1=$ Dark brown \\
\hline
\end{tabular}

\footnotetext{
*Corresponding author: andri_prasetia@ymail.com
} 


\begin{tabular}{llll}
\hline 16 & Underground tuber flesh color & $0=$ Purple; $1=$ Yellow \\
\hline 17 & Aerial tuber shape & $0=$ Oval; $1=$ spherical \\
\hline 18 & Diameter of aerial tuber & $0=<1 \mathrm{~cm} ; \quad 1=2-5 \mathrm{~cm} ; 2=6-10 \mathrm{~cm}$ \\
\hline 19 & Aerial tuber color & $0=$ Light brown; $1=$ Dark brown \\
\hline 20 & Aerial tuber flesh color & $0=$ White; $1=$ Yellow \\
\hline
\end{tabular}

\subsection{Data Analysis}

The morphological data was analyzed numerically referring to the descriptor writing provision made by the International Plant Genetic Resources Institute (Anonym, 1997) which had been modified. The analysis of morphological data began with the calculation of similarity value with the formulation of Gower's general similarity coefficient on Multivariate Statistical Program

\section{Research Results And Discussion}

\subsection{Diversity of Germplasm of Gembolo (Dioscorea bulbifera L.) in Special Region of Yogyakarta Based on Morphological Character}

(MVSP) software version 3.1pc [7], while the dendrogram was made using the technique of Unweighted Pair Group Method using Arithmetic average (UPGMA) (Singh, 1999) using the MVSP software version 3.1pc (Kovach, 2007). Principal Component Analysis (PCA) was also performed to understand the role of each morphological character in the grouping of samples.

There were 12 gembolo accessions that have been collected from 4 regencies in Yogyakarta. (Table 3).

Table 3. List of collections of gembolo obtained from the field in Special Region of Yogyakarta

\begin{tabular}{cllll}
\hline No & Collection No & Local Name & \multicolumn{1}{c}{ Origin } & Description \\
\hline $\mathbf{1}$ & KP-01 & Gembolo/ mbolo & Subdistrict of Temon, Kulon Progo Regency & Yellow Gembolo \\
$\mathbf{2}$ & BT-01 & Gembolo/ mbolo & Bantul Regency & Yellow Gembolo \\
$\mathbf{3}$ & BT-02 & Gembolo/ mbolo & Bantul Regency & Yellow Gembolo \\
$\mathbf{4}$ & BT-03 & Gembolo/ mbolo & Bantul Regency & Yellow Gembolo \\
$\mathbf{5}$ & SL-01 & Gembolo/ mbolo & Subdistrict of Prambanan, Sleman Regency & Yellow Gembolo \\
$\mathbf{6}$ & SL-02 & Gembolo/ mbolo & Subdistrict of Prambanan, Sleman Regency & Yellow Gembolo \\
$\mathbf{7}$ & SL-03 & Gembolo/ mbolo & Subdistrict of Prambanan, Sleman Regency & Yellow Gembolo \\
$\mathbf{8}$ & SL-04 & Gembolo/ mbolo & Subdistrict of Prambanan, Sleman Regency & Yellow Gembolo \\
$\mathbf{9}$ & SL-05 & Gembolo/ mbolo & Subdistrict of Prambanan, Sleman Regency & Yellow Gembolo \\
$\mathbf{1 0}$ & SL-06 & Gembolo/ mbolo & Subdistrict of Prambanan, Sleman Regency & Yellow Gembolo \\
$\mathbf{1 1}$ & SL-07 & Gembolo/ mbolo & Subdistrict of Prambanan, Sleman Regency & Yellow Gembolo \\
$\mathbf{1 2}$ & SL-08 & Gembolo/ mbolo & Subdistrict of Prambanan, Sleman Regency & Yellow Gembolo \\
\hline
\end{tabular}

(Source: researchers' personal document)

\subsection{Descriptive Analysis of Morphological Character of Gembolo}

Based on field observations on 12 accessions of gembolo plants sampled from several regions in Yogyakarta, gembolo plants had almost equal morphological form, so the variation of this plant was very small. In the sample collection process, the part of gembolo plants collected were the main tuber, leaves, and aerial tubers.

The results of observations on the accession of gembolo samples collected (Figure 1) showed that the underground tuber of gembolo was generally yellow in color, having two variations of form, i.e. spherical (regular) and irregular shapes. The main tuber flesh of gembolo was yellow, but there was a slight variation in the color of tuber flesh found in the field. In line with Coursey's (1967) research that Gembolo had two types of the main tuber, which were tubers that survive throughout the period of plant growth and annual tuber that were renewed throughout the year. Tuber flesh was white, yellow and or purple [3].

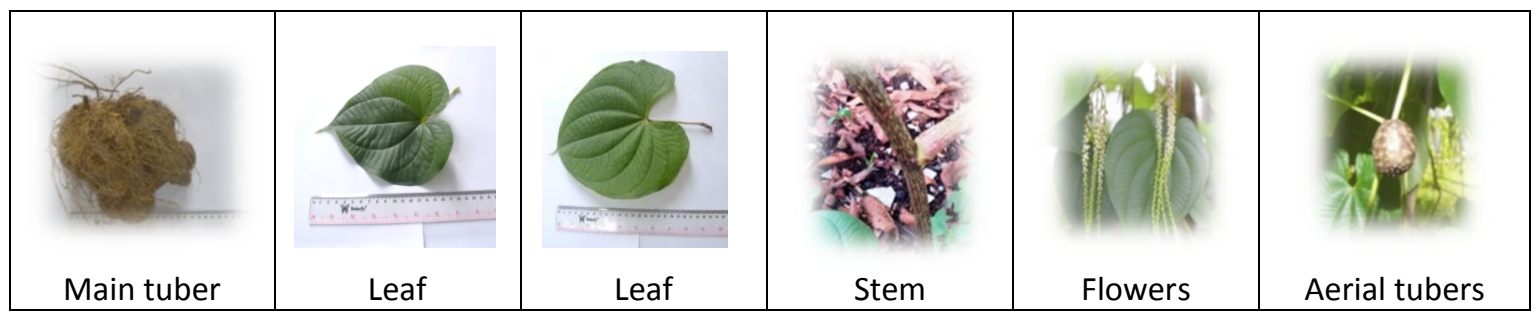


Figure 1. Gembolo morphology

(Source: researchers' personal document)

Gembolo stems were round, having smooth bumps visible along the fringe of the stem. The stem was purplish green and brownish green. Gembolo stem entirely had the twining direction to the left or counterclockwise. This was in accordance with Coursey (1967) who suggested that trailing was an important characteristic in the Dioscorea bulbifera L. species with twining direction to the left. It was also in line with Miller's (2003) study that the gembolo stems were not winged, but often have bumps/spots that were visible along the fringe of the stem. The segment of the stem was round-shaped. The stems and petioles were purplish red. Gembolo which was a dwarf species, the stems were not able to sustain the plant weight with high altitudes and many leaves, so the plants of this genus had evolved into vines [3].

Gembolo leaf shape was generally heart-shaped. But there was little difference at the base of the leaf and the leaf tip. The base of the leaf found in the field had two variations. Accession with the base of the leaf blade that opens on both sides of the blade (cordate), and accession with the base of the leaf blade which both sides are almost pile (sagittate). Leaf tips on gembolo accessions observed were generally tapered (Acuminate) and caudate. Acuminate leaf type had pointed leaf tip but the both sides was bending. Caudate leaf type had leaf tip that the main leaf venation continues to form like a tail. In line with Coursey (1967), folium simplex of gembolo was heartshaped with pointed leaf tip, 10-20 cm long, 5-15 wide. Mature leaf had a stalk that reached $8 \mathrm{~cm}$ long and the young leaves had a stalk that reached $2-3 \mathrm{~cm}$. Gembolo had a dark green leaf on the upper surface and bright green on its lower surface depending on the condition. The edges of leaves were not jagged, there were three main leaf venations in the leaves that blend into the base of the leaf.

Gembolo flowers would grow during the summer. Male and female flowers appeared together in a series, but the female flowers were more easily recognizable from the ovaries. The corolla has a purplish green-white color. The seeds on the flowers were trilocular with a length of 2 to $5 \mathrm{~cm}$ and grew vertically in bunches (Anonymous, 1974). Aerial tubers of gembolo had dark brown bark, aerial tuber flash was yellow and the average of aerial tuber diameter was $\pm 5-10 \mathrm{~cm}$. Aerial tubers would appear on the sidelines of the mature leaves after the plant entered the reproductive period when the plant was \pm 3 months old [1]. Aerial tubers would survive on the stem during the life cycle of gembolo of 8 to 10 months. Once the plant entered the harvest period, the aerial tuber would fall to the ground by itself, experiencing dormancy during the dry season, and would re-grow during the rainy season [3].

\subsection{The Relationship of Intraspecies of Gembolo (Dioscorea bulbifera L.) Based on Morphological Character}

Based on the 12 accessions of gembolo observed, there were 20 morphological characters that could be used to analyze the morphological variation and the phenetic relationship of gembolo. The morphological character consisted of 15 qualitative characters and 5 quantitative characters

In this research, two kinds of morphological data analysis method were used, namely cluster analysis and principal component analysis aimed to know the role of the morphological character in gembolo accession grouping in the Special Region of Yogyakarta. In the research of Plant Systematics, the methods of cluster analysis and principal component analysis were methods that were commonly used (Henderson, 2006). The gembolo accession grouping was based on the value of similarity among accessions calculated using the formulation of Gower's general similarity coefficient formula, the use of this formula was chosen because it was appropriate to use because of the combination of qualitative and quantitative characters (Gower, 1971). The cluster analysis was done using the UPGMA method [11]. 


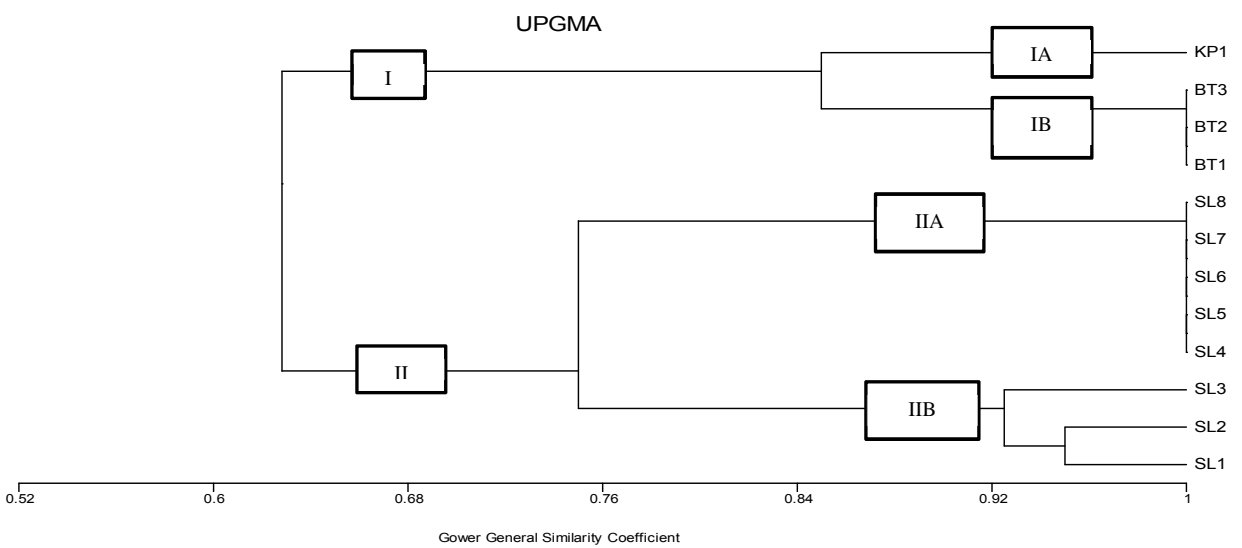

Figure 2. The dendrogram which shows the grouping and the relationships of Gembolo based on morphological characters

\begin{tabular}{|c|c|c|c|}
\hline No. & Characters & Grup I & Grup II \\
\hline 1. & Tuber Shape & Irregular & Regular \\
\hline 2. & Stem Color & Green & $\begin{array}{l}\text { Purplish } \\
\text { green }\end{array}$ \\
\hline 3. & $\begin{array}{l}\text { Leaf blade base } \\
\text { shape }\end{array}$ & Sagittate & Cordate \\
\hline 4. & Leaf tip shape & acuminate & Caudate \\
\hline 5. & Young leaf color & $\begin{array}{l}\text { Bright /light } \\
\text { green }\end{array}$ & Purple \\
\hline
\end{tabular}

The results of cluster analysis in Figure 2 showed that there were 2 main groups formed with $62.8 \%$ similarity index which were marked as group I and group II on the dendrogram. The group I and group II were formed because of the differences in the morphological character of tuber shapes, stem color, leaf shape, leaf base shapes, and leaf tip shapes. Group I consisted of four accessions with a similarity value of $85 \%$. Group II consisted of eight accessions that were divided by a similarity value of $75 \%$.

The grouping of gembolo accessions from different regions into a group with the similarity value of $80 \%$ occurring on the dendrogram did not show any firm grouping. In line with Purnomo's research (2015), the distribution of gembolo (Dioscorea bulbifera L.) was more dominant through tubers, so the morphological character had $100 \%$ similarity value and did not show any significant grouping.

In general, the morphological characters of 12 gembolo accessions collected from several areas in Yogyakarta had a high degree of similarity, so that the differentiating factors of morphological characters were few. The differentiating character between groups I and II is summarized in Table 4.

Table 4. Differentiating character between members of Group I and Group II on the Gembolo Accession Grouping

The principal component analysis was performed to understand the role of each morphological character in the sample grouping. The results showed the same grouping as the clustering pattern of gembolo accession and morphological character distribution pattern (Figure 3).

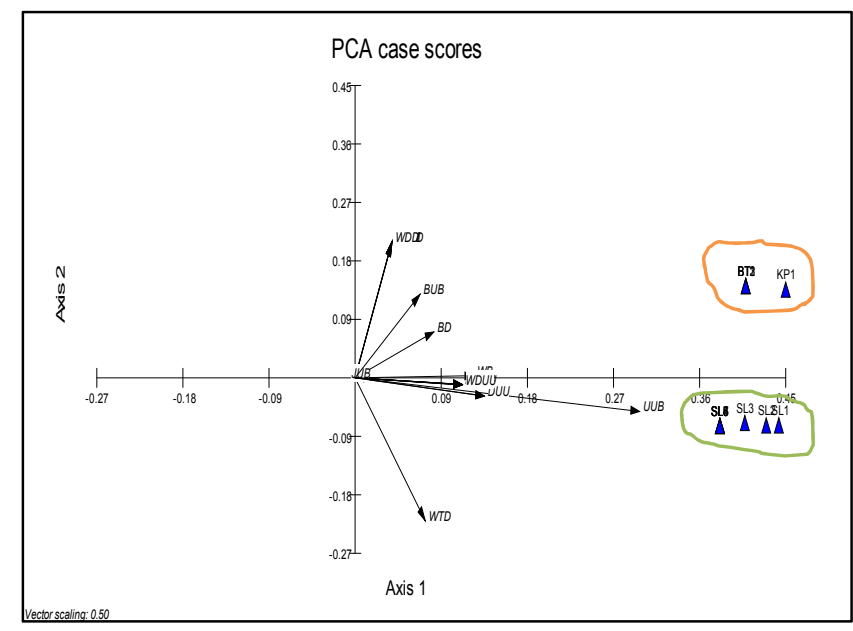

Fig. 3. Diagram of gembolo accession grouping pattern and morphological character distribution pattern

The result of principal component analysis to 20 morphological characters of gembolo showed that the total variation seen in axis 1 was $92,167 \%$ with an eigenvalue of 1,974 and axis 2 was $5,655 \%$ with an eigenvalue of 0,121 .

Based on the eigenvalue, it was known that the grouping separated by the first axis, which divided 12 gembolo accessions into groups I and II was mainly influenced by the factor of underground tuber shape, stem color, leaf shape, mature leaf color, petiole color, underground tuber size, aerial tuber diameter and aerial tuber flesh color. In line with the research of Purnomo et al. (2012) which stated that morphological characters affecting the separation of green and purplish red cultivar groups on Dioscorea alata L. plants were tuber shape, tuber flesh color, leaf tip and leaf base, petiole base and leaf venation. 


\section{Conclusions}

Species of Gembolo (Dioscorea bulbifera L.) in Special Region of Yogyakarta based on morphological characters had a diversity that could be seen from the morphological character of the tuber shape, stem color, the leaf shape, the shape of the leaf blade base and the shape of the leaf tip.

Based on the morphological approach using samples from different regions of Yogyakarta, it could be indicated that the species of gembolo (Dioscorea bulbifera L.) were in the same species. The presence of very high similarity based on the molecular analysis of gembolo accessions indicated that gembolo was not a varied plant.

\section{References}

1. Anonym, 1974. Tropical Yams and Their Potential Part 2. Dioscorea bulbifera. Agricultural Research Service. United States Department of Agriculture. Washington D.C.

2. Anonym, 1997. Descriptors for Yam (Dioscorea spp.). International Institute of Tropical Agriculture, Ibadan, Nigeria/International Plant Genetic Resources Institute, Rome, Italy.

3. Coursey, D.G. 1967.Yams. An Account of the Nature, Origins, Cultivation and Utilization of the Useful Members of the Dioscoreaceae. London: Longman.

4. Gower, J. C. 1971. A General Coefficient of Similarity and Some of Its Properties. Biometrics, 27: 857-874.
5. Henderson, A. 2006. Traditional Morphometrics in Plant Systematics and It's Role in Palm Systematics. Bot. J. Linn. Soc., 151: 103-111

6. Heyne, K. 1987. Tumbuhan Berguna Indonesia. Jilid III. Badan Litbang Kehutanan. Jakarta.

7. Kovach, W.L. 2007. MVSP-A Multivariate Statistical Package, 3.1. Kovach Computing Service, Pentraeth, Wales.

8. Purnomo., Daryono., B.S, Rugayah., \& Sumardi, I. 2012. Studi etnobotani Dioscorea spp. (Dioscoreaceae) dan Kearifan Budaya Lokal Masyarakat di Sekitar Hutan Wonosadi Gunungkidul Yogyakarta. Jurnal Natur Indonesia 14 (3) : 191-198

9. Purnomo. 2013. Biosistematika Tanaman Uwi (Dioscorea alata L.) dan Spesies Kerabat Dekatnya Di Indonesia Berdasarkan Penanda Morfologis, Anatomis dan Molekular. Dissertation (unpublished), Faculty of Biology UGM, Yogyakarta

10. Purnomo, 2015. Variability and Intraspecies Classification of Gembolo (Dioscorea bulbifera L.) in Yogyakarta and Surronding Areas Based on Morphological Characters. International Seminar on "Natural Resources Biotechnology: From local to Global" Held on Universitas Atma Jaya. Yogyakarta.

11. Singh, G. 1999. Plant Systematics. New Hampshire: Science Publisher

12. Sokal, R. \& Sneath, H. A. P. 1963. Principle of Numerical Taxonomy. The University of Kanzas and Natural Institude For Medical Research: London

13. Steeins, van C. G. G. J, Bloembergen, S. \& Eyme, P.J. 2013. Flora. Jakarta Timur: PT. Balai Pustaka 